\title{
Pathogenic viruses and viral vectors in plants: A comprehensive review
}

\author{
Azra Alimanović ${ }^{* 1}$, \\ ${ }^{1}$ Genetic and Bioengineering Department, International University of Sarajevo
}

*Corresponding author: aalinanovic@ius.edu.ba (C) The Author 2021.

Published by ARDA.

\begin{abstract}
Viruses are extremely small obligate molecular parasites that can be seen only with an electron microscope. In plant pathology there are the organisms named plant viral vectors whose task is to transmit pathogens. Transmission of vector can be mechanical and insect that present two pathways which allow the spreading of plant virus particles. Plant virologists with other association in molecular biology and plant pathology nominated top 10 viruses based on scientific and economic importance. This paper reviews the current standing of most known antiviral defense mechanism called RNA silencing and most known molecular diagnostic method in plant pathology, polymerase chain reaction (PCR).

(2,

Keywords: Plant virus, Viral vector, RNA silencing, Polymerase chain reaction (PCR)
\end{abstract}

\section{Introduction}

In biology the 1890s is characteristic for the study of viruses with disclosure of an acute infectious agent in tobacco causing leaf spots. The first virus characterized is tobacco mosaic virus (TMV), which is characterized also as first agents of disease among plant viruses [1]. Virus is submicroscopic infection agent (virions) [2]. After fungi, the viruses belong to the second category of the most important pathogens [3]. Viruses are really, really small, and unlike to bacteria and fungi, we cannot see them with the normal light microscope, so we can see him only using very high resolution microscopy, such as the electron microscope. The goal of every virus is to reproduce through all cellular life and infect cells. The make people, animal and plant sick. Viruses are parasitic, the main reason for it is that they cannot exist on their own, and they cannot replicate [2].

One level of classification viruses include families and genera based on the size, shape and type of capsid and their nucleic acid, as well as presence or absence of lipid envelope surrounding the nucleocapsid. Plant viruses are grouped into 73 genera and 49 families according to the International Committee on Taxonomy of Viruses (ICTV). Most of the viruses were currently recognized from cultivated plants which in turn represent only a very small fraction of the total number of plant species. [4].

It is known fact for viruses that in mature form, virus particle, known as virions are composed of two structures, genome made of nucleic acid, and a protective shell made of protein. Genome of plant viruses are composed mainly of a nucleic acid, either DNA or RNA, normally surrounded by a protein shell (coat) [5].The genome may be a single molecule (monopartite) or may be divided into two or more pieces (bipartite or multipartite) [6]. About $75 \%$ of plant viruses genomes consist of single stranded RNA (ssRNA).

While more than $65 \%$ of plant viruses have positive sense ssRNA, and the rest of the $10 \%$ have negative sense ssRNA [7].

This work is licensed under a Creative Commons Attribution License (https://creativecommons.org/licenses/by/4.0/) that allows others to share and adapt the material for any purpose (even commercially), in any medium with an acknowledgement of the work's authorship and initial publication in this journal. 
Several plant viruses, beside the coat proteins, have a lipid envelope [8]. Virus lipid envelope is composed of proteins which are of great importance to the virus while lipids and carbohydrates primarily taken from the cell which is infected. In some cases, organelle structures like mitochondria and lysosomes are not the part of complex viral particles [9]. Protein shells of plant viruses, named capsid are assembled in one of the two basic types of symmetry. The first type of virion is roughly elongated, named helical. Two versions of elongated viruses are presented, rigid rods and flexuous filaments. In both of these versions, the proteinaceous capsid has helical conformation and the nucleic acid also assumes the same conformation, means that it is highly regulated. Spherical version of virus particle is icosahedral. Bacilliform virions and twin virions composed of two joined incomplete icosahedra are the versions of this virus shape. Genomic nucleic acid create partially ordered ball inside the proteinaceous capsid which belongs to the icosahedral form of virions. If the nucleic acid and protein subunits are incubated under proper conditions these two types of virions, helical and icosahedral can self compose in the test tube [10]. Large numbers of plant viruses have rod-shaped (flexuous or rigid) structure. The average length of viral particle is between $300-500 \mathrm{~nm}$ along with a diameter of 15 20nm, depends of the genome [11]. Around the circumference of a circle in viruses the protein subunits are placed and often form a disc. Complex tube-like structures are formed by variants and have a cavity in middle with a certain shape in which a genome of nucleic acid is located [12].

Persistent, acute, chronic and endogenous are the four different lifestyles forms which belong to the plant viruses. Some viruses have ability to change from one lifestyle to another, usually between acute and chronic lifestyles, also other mentioned lifestyle changes occur, but they are rare [13].

Replication occurs in compatible cells, usually with the induction of symptoms in the affected plant. The known smallest infectious agents are viroids. These little infectious agents have circular, single-stranded ribonucleic acid (RNA) molecule less than one-tenth the size of the smallest viruses [5].

\section{Plant viral vectors}

Viruses in plants have been engineered as vectors for biopharmaceutical and therapeutic protein production, some of them for commercial field, as also express the monoclonal antibodies and vaccines. In the field of plant functional genomics studies in purpose for targeting and down regulating plant viral vectors have the important function as a research tool by incorporating virus induced gene silencing (VIGS) . Today, technology ah high level offer the great implications for the development of crops with improved characteristics, and has the potential for manifesting rising dynamics of new era for the production of biologics. Benefiting human beings, plant viral vectors have possibility to express endogenous and foreign polypeptides to help controlling agronomic properties or in production of vaccines and valuable carotenoids. As nano-particles, plant viruses have recently been engaged in new forms of cancer treatment, which have also been created to act as adjutants in eliciting an immune response that is stronger and more effective [14]. A large number of plant viral vectors have been developed for genome editing based on CRISPR/Cas9 model and crop plants [15]. Using vectors offers a useful tool for the large-scale production of proteins which are significant for industrial field, such as antibodies and vaccine antigens for the transient expression of heterologous proteins [16]. Plant viral vectors are made from the genomes of positive RNA viruses or singlestranded DNA viruses. These vectors are successfully developed and exploited as have great power in agricultural, biomedical and industrial scale expression where they have the great impact as a research tool to study gene expression and reduce time and cost in modulating gene expression [17].

Primarily, the engineering strategy (termed as a 'full virus' vector strategy) form a vector that was essentially a wild type virus, modified to carry and express a heterologous sequence encoding a gene of interest. The emerging new trend (the vector strategy of the 'deconstructed virus') reflects an ideology that recognizes the inherent limitations of the viral process. Eliminating the functions that are limited or unwanted, and restoring them, it tries to 'deconstruct' the virus either by delegating the missing required functions to the host (which is genetically modified to provide those functions) or by replacing analog functions that are not derived from a virus [18]. 


\section{Most common viruses in invading plants}

\section{a. Tobacco mosaic virus (TMV)}

In the history of virology the first and unique place belongs to tobacco mosaic virus (TMV) [19] .This more specific virus was found over a century ago and belongs to a large group of viruses within the genus Tobamovirus. It can infect over 350 different species of plants. Tobacco, tomato, and other members of Solanaceous family are the hosts for TMV [20]. TMW looks like a stick. Its capsid is made up of 2130 protein molecules and one RNA molecule containing the virus genome and is made up of 6400 basic units.RNA is located at radius approximately of $6 \mathrm{~nm}$ and is protected by capsid from the influence of cellular enzymes. One characteristic for TMV virus is that it is both chemically and physically stable to solvents with $\mathrm{pH}$ (3.59.0), temperature (up to $90^{\circ} \mathrm{C}$ ), and reducing agents [21].

\section{b. Tomato spotted wilt virus (TSWV)}

Tomato spotted wilt virus (TSWV) for the first time is described in Australia and from year 1930 the virus is part of viral etiology, belongs to the family Bunyaviridae with the genus Tospovirus. When an infection occurs it affects approximately about 1000 species in over 85 families, including vegetables, legumes, ornamentals, peanut and tobacco. Structure of TSWV is complex and characteristic, and that is one of the reason why it is distinguished from most other plant viruses. Virus particle are roughly spherical and complex compared to many plant viruses. Genome of virus has three RNAs which are individually encased, and are collectively bound by a membrane envelope that is of host origin [22].

\section{c. Tomato yellow leaf curl virus}

DNA virus, tomato yellow leaf curls (TYLCV) belongs to the family Geminiviridae in the genus Begomovirus. The virus is a monopartite DNA virus with circular genome encapsidated in a twinned icosahedral virion. Genome of TYLCV contains six genes with two genes on the viral strand (V1-V2) and four genes on the complementary sensory chain (C1-C4). TYLCV can be found in tropical and subtropical regions, whose primary host is domesticated tomato (Solanum lycopersicum). This kind of virus can cause the most destructive disease of tomato [23].

\section{d. Cucumber mosaic virus (CMV)}

In the genus Cucumovirus and family Bromoviridae, plant pathogenic virus named Cucumber mosaic virus $(C M V)$ is located. Virus structure consists of three spherical particles with $28 \mathrm{~nm}$ in diameter. CMV genome consists of three different RNA molecules, designated RNA 1 ( $\sim 3,350$ nucleotides), RNA 2 ( $\sim 3,050$ nucleotides) and RNA 3 ( 2,200 nucleotides). RNA molecules have protective protein coat with single spherical-shaped particle. Infection caused by CMV virus can cover approximately about 1200 species in over 100 families of monocots and dicots, including many vegetables, such as pumpkin, melon, peppers, beans, tomatoes, celery, carrots, lettuce, spinach and beets, than ornamentals, woody and semi-woody plants. [24]

\section{e. Cauliflower mosaic virus (CaMV)}

Cauliflower mosaic virus (CaMV) is a member of the genus Caulimovirus belongs to the Caulimoviridae family of circular, double-stranded DNA viruses. The CaMV belongs to the group of pararetroviruses and it is one of the six genera that cause infection of Brassicaceae family members, including turnip, canola, radish, mustard, cauliflower, broccoli, and cabbage [27].

\section{f. Plum pox virus (PPV)}

Plum pox virus (PPV) has flexuous rod-shaped particles whose single-coat protein encapsidating a single molecule of positive sense, ssRNA and belongs to the genus Potyvirus. PPV cause disease called plum pox 
and infect a large number of stone grown fruit species including: plum, apricot, almond, cherry, peach, and nectarine, wild and ornamental Prunus [29].

\section{g. Brome mosaic virus (BMV)}

Brome mosaic virus (BMV) is a positive-stranded, icosahedral RNA, type member of the genus Bromovirus in the family Bromoviridae [30]. BMV infects monocotyledonous cereal crops such as barley, maize, rice, wheat, and sorghum causing mosaic symptoms and stunting [31].

\section{h. Potato virus X (PVX)}

Potato virus $X(P V X)$ is a single-stranded RNA plant pathogenic virus has a simple filamentous flexible structure of about $500 \mathrm{~nm}$ in length and $15 \mathrm{~nm}$ in diameter belongs to the genus Potexvirus of the Flexiviridae family. PVX can infect a wide range of crops in the family Solanaceae including tomato, potato, pepper and tobacco. It can be transmitted mechanically or contact between plants [32]. In table 1 we represent the most common plant viruses.

\section{i. African cassava mosaic virus (ACMV)}

African cassava mosaic virus (ACMV) is the member of the genus Begomovirus, in the family Geminiviridae. This virus is bipartite. DNA molecule code for two movement proteins. ACMV cause endemic Cassava mosaic disease (CMD) which is a major constraint on cassava cultivation in Africa [28].

\section{j. $\quad$ Potyvirus (PVY)}

Potyvirus $(P V Y)$ is one of the six genera in the family Potyviridae. PVY affect field-grown vegetables such as potato, pepper, tomato, and tobacco causing severe losses on all these hosts. It is currently recognized as the most damaging potato virus in the world for seed and processed potatoes [25]. It exists as a complex of strains that have developed through accumulation of mutations and recombination, allowing the virus to adapt effectively to new potato varieties [26].

Table 1: Common plant viruses

\begin{tabular}{|c|c|c|c|c|}
\hline No & Virus & Genus & Host & Structure \\
\hline 1. & Tobaco mosaic virus & Tobamovirus & $\begin{array}{l}\text { Tobacco, tomato, } \\
\text { members of Solanaceous } \\
\text { family }\end{array}$ & $\begin{array}{l}\text { Rod-like structure, } \\
\text { positive-sense ssRNA }\end{array}$ \\
\hline 2. & Tomato spotted wilt virus & Tospovirus & Vegetable, peanut, tobbaco & $\begin{array}{l}\text { Spherical, negative- } \\
\text { sense RNA }\end{array}$ \\
\hline 3. & Tomato yellow leaf curl virus & Begomovirus & Domesticated tomato & $\begin{array}{l}\text { Monopartite DNA with } \\
\text { circular ssDNA genome }\end{array}$ \\
\hline 4. & Cucumber mosaic virus & Cucumovirus & $\begin{array}{l}\text { Ornamentals, woody and } \\
\text { semi-woody plants }\end{array}$ & $\begin{array}{l}\text { Linear positive-sense, } \\
\text { tripartite ssRNA }\end{array}$ \\
\hline 5. & Potato virus $Y$ & Potyvirus & $\begin{array}{l}\text { Potato, pepper, tomato, } \\
\text { tobbaco }\end{array}$ & $\begin{array}{l}\text { Aphid-borne virus, } \\
\text { monopartite ssRNA }\end{array}$ \\
\hline 6. & Cauliflower mosaic virus & Caulimovirus & $\begin{array}{l}\text { Radish, cabbage, mustard, } \\
\text { broccoli, turnip }\end{array}$ & Circular, dsDNA \\
\hline 7. & African cassava mosaic virus & Begomovirus & African cassava & $\begin{array}{l}\text { Bipartite }, 2^{\text {nd }} \text { DNA } \\
\text { molecule coding for two } \\
\text { movement protein }\end{array}$ \\
\hline 8. & Plum pox virus & Potyvirus & $\begin{array}{l}\text { Plum, peach, nectarine, } \\
\text { almond }\end{array}$ & Flexous rod-shaped \\
\hline 9. & Brome mosaic virus & Bromovirus & $\begin{array}{l}\text { Monocotyledonous cereal } \\
\text { crops }\end{array}$ & $\begin{array}{l}\text { Small, positive- } \\
\text { stranded,icosahedral } \\
\text { RNA }\end{array}$ \\
\hline 10. & Potato virus $X$ & Potexvirus & Potatoes & ssRNA pathogenic \\
\hline
\end{tabular}




\section{Antiviral mechanism: RNA silencing}

Large numbers of different viruses are potential causes of infection in plants. Virus particles may enter plants by mechanical inoculations, insect feeding, or in vegetative propagation. When it comes to infection the plants, it may be start with an insect bite, as also one pathway of the infection is that the virus reaches a single cell to initiate infection. There are different defense mechanisms against viruses in plants, such as RNA silencing, translational repression, innate immunity, autophagy-mediated protein degradation and ubiquitination-mediated. In the last decade research in the dominant resistance genes resulted in the identification of some antiviral proteins that limit viral proliferation by direct interaction with and inhibition of viral protein functions. The main fact is that viruses cannot do anything by themselves. Eventually, the offspring viruses are released into neighboring cells and this cycle is repeated. The known fact is that here are approximately 450 species of plant-pathogenic viruses, which cause a range of diseases by infecting the cells of plants [33].

Viruses cause significant economic losses due to disease and infection that causes in plants through reduction in crop quality and quantity to the point of endangering food safety in some countries. Genetic resistance to viruses has been successfully designed for some combinations of plants and viruses due to given reduced availability of natural sources. As it already known, humans and animals have an immune system to fight viral infections. Interestingly, plants also have an immune system. The basic mechanisms govern interaction of plant and virus, in case where it include antiviral RNA silencing, are the basis to devising better management strategies and biotechnological approaches for engineering and application of antiviral resistance in plants [34].

In plants, a process known as gene silencing is a very effective way to fight against virus. RNA silencing is one of the molecular mechanisms at which plants resist viruses. In many cases, RNA silencing is considered the most important basal adaptive plant antiviral defense response and considered as ubiquitous gene regulation mechanism, based on the creation of small RNAs leading to complementary nucleic acids attenuation apparatus for transcriptional gene silencing (TGS) or post-transcriptional gene silencing (PTGS) [35].

RNA silencing plays have important role in plant resistance against viruses, with impact number of silencing factors involved in antiviral defense. Series of proteins are required for normal participation in the regulation of cellular gene expression. Unfortunately for plants, viruses don't give up quickly and they almost always have some other abilities to produce special proteins with the power to interfere with plant defenses [33].

Both RNA and DNA viruses are targeted by a small pathway of RNA-directed degradation of RNA with DNA viruses, also being targeted by RNA-directed DNA methylation [36].

Expression of RNA silencing suppressors or adopting silencing resistant RNA structures are defense mechanism which plant viruses developed to avoid RNA silencing. Recent research has shown that RNA silencing also plays a direct role in induction viral disease in plants, with viral suppressors for RNA silencing and viral siRNAs as potentially the dominant players in viral pathogenicity. It is difficult to answer is RNA silencing has the role as major mediator of viral pathogenicity or if other RNA silencing also include the induction of viral disease. RNA silencing is used as a powerful tool for engineering virus resistance in plants and also in animals. Further understanding of the role of RNA silencing in plant-virus interactions and induction of viral symptoms is likely to result in new antiviral strategies in both plants and animals [37].

\section{Molecular diagnostic method for plant viruses}

Most of the viruses cause agronomic, economic and social impact and losses of plants due to the infections and different disease state. To reduce these economic losses it is very important to reveal the viruses at early stages. The important and most useful molecular detection technique for detection and identification the viral nucleic acid directly and to determine the virus circulation in plants with the advantages od high sensitivity and reproducibility is powerful method, polymerase chain reaction (PCR) which offer rapid and accurate 
detection due to optimized clinical care and limit spread of viruses with rapid response. PCR named in more scientific researches as 'gold standard' of molecular methods used for sensitive and specific viral detection. All diagnostic tests for this purpose need to be rapid, cheap, accurate, and applicable. PCR technique is specific method for detection a wide variety of templates across a range of scientific specialties, including virology. PCR present specific method and essential tool in research laboratory for detection of virus infection and useful indicator of disease caused by viruses. In molecular diagnostics using polymerase PCR provide gold standard for detection nucleic acid. During PCR, fragment of viral genome is amplified using specific primers. The method utilizes a pair of synthetic oligonucleotides or primers, each hybridizing to one strand of a double-stranded DNA (dsDNA) target make millions DNA copies of specific region of the viral genome. PCR process are summarized in three basic steps : (i) dsDNA separation at temperatures $>90^{\circ} \mathrm{C}$, (ii) primer annealing at $50-75^{\circ} \mathrm{C}$, and (iii) optimal extension at $72-78^{\circ} \mathrm{C}$. The rate of temperature change, the length of the incubation at each temperature and the number of times each set of temperatures (or cycle) is repeated is controlled by a programmable thermal cycler [38]. Using specific primers, PCR successfully can detect both, pathogenic DNA and RNA viruses. For RNA viruses, RT of viral RNA to a cDNA strand is necessary prior to PCR. During reverse transcription, primer is necessary for RNA-dependent DNA polymerase for initiation synthesis of cDNA from RNA. Each set of primers are designed for detection of each particular virus. Some genes in viral genome offer opportunity for designing primers which are capable for hybridizing with several members in viral family and allow the amplification of genomic sequences for many members of a virus genus [39]. The efficiency of reaction is enhanced by several parameters, including primer specificity, inhibitors, different types of enzyme, composition of buffer, quality of nucleic acid targets and stability of reaction. Sets of primers used for PCR reaction are designed for the detection of each remarkable virus. Using multiple primer sets with a single PCR such as multiplex PCR, can be used for simultaneous detection different groups of viruses. But, it can be difficult for optimization because of different annealing temperature requirements of different primer sets and potential different properties of the viral nucleic acids found between viral groups. Using real-time PCR can measure the amount of two nucleic acid targets with a single reaction. Real-time PCR combined with software packages has made the quantitative detection of plant viruses available to diagnostic laboratory [40].

\section{Conclusion}

Plant viruses are group of pathogens that cause infections and diseases in plant crops. The top 10 list includes, in rank order, Tobacco mosaic virus, Tomato spotted wilt virus, Tomato yellow leaf curl virus, Cucumber mosaic virus, Potato virus Y, Cauliflower mosaic virus, African cassava mosaic virus, Plum pox virus, Brome mosaic virus and Potato virus X. In plants, a born defense mechanism, the RNA silencing pathway, plays an essential role in antiviral defense. The most familiar and commonly used molecular identification method of plant viruses is the Polymerase chain reaction method (PCR).

\section{References}

[1] M. W. Beijerinck, Concerning a Contagium Vivum Fluidium as a Cause of the Spot-Disease of Tobacco Leaves. APS book, 1942.

[2] D. R. W. Williamson, "What are viruses?," 2008. [Online]. Available: https://www.sciencelearn.org.nz/videos/58-what-are-viruses. [Accessed: 01-Nov-2021].

[3] Anne K. Vidaver and Patricia A. Lambrecht, "Bacteria as Plant Pathogens," APS, 2004.

[4] I. Cooper and R. A. C. Jones, "Wild plants and viruses: under-investigated ecosystems," Adv. Virus Res., vol. 67, pp. 1-47, 2006.

[5] M. H. Van Regenmortel, J. Maniloff, and C. Calisher, "The concept of virus species," Arch. Virol., vol. 120, no. 3-4, pp. 313-314, 1991.

[6] J. A. Lucas, Plant Pathology and Plant Pathogens, 4th ed. Nashville, TN: John Wiley \& Sons, 2020.

[7] C. M. Fauquet, M. A. Mayo, J. Maniloff, U. Desselberger, and L. A. Ball, Virus taxonomy: Eighth report of the international committee on taxonomy of viruses. Elsevier Science \& Technology, 2004.

[8] M. Breitbart and F. Rohwer, "Here a virus, there a virus, everywhere the same virus?," Trends 
Microbiol., vol. 13, no. 6, pp. 278-284, 2005.

Emergency Collection, 2014.

[10] K. S. Sastry, "Plant virus and viroid diseases in the tropics, Volume 1: Introduction of plant viruses and sub-viral agents, classification, assessment of loss, transmission, and diagnosis.".

[11] S. M. Gray and N. Banerjee, "Mechanisms of arthropod transmission of plant and animal viruses," Microbiol. Mol. Biol. Rev., vol. 63, no. 1, pp. 128-148, 1999.

[12] B. V. V. Prasad and M. F. Schmid, "Principles of virus structural organization," Adv. Exp. Med. Biol., vol. 726, pp. 17-47, 2012.

[13] E. Waigmann and M. Heinlein, Viral Transport in Plants. Berlin, Germany: Springer, 2007.

[14] K. Hefferon, "Plant virus expression vector development: new perspectives," Biomed Res. Int., vol. 2014, p. 785382, 2014.

[15] S. S.-E.-A. Zaidi and S. Mansoor, "Viral vectors for plant genome engineering," Front. Plant Sci., vol. 8, p. 539, 2017.

[16] Y. Gleba, V. Klimyuk, and S. Marillonnet, "Viral vectors for the expression of proteins in plants," Curr. Opin. Biotechnol., vol. 18, no. 2, pp. 134-141, 2007.

[17] W. B. Cody and H. B. Scholthof, "Plant virus vectors 3.0: Transitioning into synthetic genomics," Annu. Rev. Phytopathol., vol. 57, no. 1, pp. 211-230, 2019.

[18] Y. Gleba, S. Marillonnet, and V. Klimyuk, "Engineering viral expression vectors for plants: the "full virus' and the 'deconstructed virus' strategies," Curr. Opin. Plant Biol., vol. 7, no. 2, pp. 182-188, 2004

[19] B. W. J. M. A. M. H. V. Van Regenmortel, Encyclopedia of Virology. Science direct, 2008.

[20] K.-B. G. Scholthof et al., "Top 10 plant viruses in molecular plant pathology: Top 10 plant viruses," Mol. Plant Pathol., vol. 12, no. 9, pp. 938-954, 2011.

[21] K. C. Holmes, "Flexibility in tobacco mosaic virus," Ciba Found. Symp., vol. 93, pp. 116-138, 1983.

[22] Sherwood, J. L., German, T. L., Moyer, and J.W. and D.E. Ullman. 2003. Tomato spotted wilt, "Tomato spotted wilt virus," he Plant Health Instructor, 2009.

[23] W. G. Marchant, S. Gautam, S. F. Hutton, and R. Srinivasan, "Tomato yellow leaf curl virus-resistant and -susceptible tomato genotypes similarly impact the virus population genetics," Front. Plant Sci., vol. 11, p. 599697, 2020.

[24] Zitter, T. A., and A. J. F. Murphy, "Cucumber Mosaic Virus," The Plant Health Instructor., 2009.

[25] B. W. J. M. A. M. H. V. Van Regenmortel, Encyclopedia of Virology. Science Direct, 2008.

[26] Y. Mao et al., "Molecular evolutionary analysis of potato virus Y infecting potato based on the VPg gene," Front. Microbiol., vol. 10, p. 1708, 2019.

[27] A. Bak and J. B. Emerson, "Cauliflower mosaic virus (CaMV) biology, management, and relevance to GM plant detection for sustainable organic agriculture," Front. Sustain. Food Syst., vol. 4, 2020.

[28] C. M. F. Nawaz-ul-Rehman, "Emerging Geminiviruses," in Encyclopedia of Virology (Third Edition), B. W. J. M. A. M. H. V. Van Regenmortel, Ed. Academic Press, 2008.

[29] G. P. Lomonossoff, “Antigen Delivery Systems III: Use of Recombinant Plant Viruses," in Mucosal Immunology (Third Edition), M. E. L. et Jiri Mestecky, Ed. Academic Press, 2005.

[30] G. P. Lomonossoff, "Antigen Delivery Systems III: Use of Recombinant Plant Viruses," in Mucosal Immunology (Third Edition), M. E. L. Jiri Mestecky, Ed. 2005.

[31] P. A. X. Wang, "Brome Mosaic Virus," in Encyclopedia of Virology (Third Edition), B. W. J. M. A. M. H. V. Van Regenmortel, Ed. 2008.

[32] C. Lico, E. Benvenuto, and S. Baschieri, "The two-faced potato virus X: From plant pathogen to smart nanoparticle," Front. Plant Sci., vol. 6, p. 1009, 2015.

[33] H. Garcia-Ruiz, "When viruses infect plants," Scientia (Bristol), vol. 2019, no. 123, pp. 40-43, 2019.

[34] H. Garcia-Ruiz, M. T. G. Ruiz, S. M. G. Peralta, C. B. M. Gabriel, and K. El-Mounadi, "Mechanisms, applications, and perspectives of antiviral RNA silencing in plants," Rev. Mex. Fitopatol., vol. 34, no. 3, 2016.

[35] A. E. Martínez de Alba, E. Elvira-Matelot, and H. Vaucheret, "Gene silencing in plants: a diversity of pathways," Biochim. Biophys. Acta, vol. 1829, no. 12, pp. 1300-1308, 2013.

[36] M.-B. Wang, C. Masuta, N. A. Smith, and H. Shimura, "RNA silencing and plant viral diseases," Mol. Plant. Microbe. Interact., vol. 25, no. 10, pp. 1275-1285, 2012.

[37] I. M. Artika, A. Wiyatno, and C. N. Ma'roef, "Pathogenic viruses: Molecular detection and characterization," Infect. Genet. Evol., vol. 81, no. 104215, p. 104215, 2020.

[38] K. B. Mullis and F. A. Faloona, "Specific synthesis of DNA in vitro via a polymerase-catalyzed chain 
reaction," Methods Enzymol., vol. 155, pp. 335-350, 1987.

[39] A. Olmos, E. Bertolini, M. Gil, and M. Cambra, "Real-time assay for quantitative detection of nonpersistently transmitted Plum pox virus RNA targets in single aphids," J. Virol. Methods, vol. 128, no. 1-2, pp. 151-155, 2005.

[40] B. S. H. de Elphinstone J. G. Saddler G. S., "Biotechnology and plant disease management," in Biotechnology and plant disease management, Punja, Z. K., Boer, S. H. de, Sanfaçon, H., Ed. CABI, 2007, pp. 165-194. 